\title{
Presence of high-grade intraepithelial lesions among women deprived of their liberty: a documental study
}

\author{
Paula Renata Amorim Lessa ${ }^{1}$ \\ Samila Gomes Ribeiro ${ }^{1}$ \\ Diego Jorge Maia Lima ${ }^{1}$ \\ Ana Izabel Oliveira Nicolau² \\ Ana Kelve de Castro Damasceno ${ }^{3}$ \\ Ana Karina Bezerra Pinheiro ${ }^{3}$
}

\begin{abstract}
The aim of this study was to analyze the results of the Pap smears of women deprived of their liberty. It is a retrospective, documental study, with a quantitative approach, performed in a female prison of Ceará, Brazil, with a sample of 672 patient records. Regarding the microbiological findings, it was verified that the main cervical-vaginal colonization was by bacilli suggestive of Gardnerella/Mobiluncus (21.8\%), followed by Trichomonas vaginalis $(12 \%)$, and Candida sp $(5.8 \%)$. The frequencies of samples with atypical cells presented rates of $4.1 \%$ for Atypical Cells of Undetermined Significance; $3.2 \%$ for Low-grade Intraepithelial Lesions; and $2.5 \%$ for High-grade Intraepithelial Lesions. The importance of screening for cervical cancer in female prisons was highlighted, as well as the inclusion of the nurse in this environment, ensuring individualized, quality care for women deprived of their liberty.
\end{abstract}

Descriptors: Uterine Cervical Neoplasms; Prisons; Nursing.

\footnotetext{
${ }^{1}$ Master's students, Departamento de Enfermagem, Universidade Federal do Ceará, Brazil.

2 MSc, Assistant Professor, Departamento de Enfermagem, Universidade Federal do Piauí, Brazil.

${ }^{3}$ PhD, Adjunct Professor, Departamento de Enfermagem, Universidade Federal do Ceará, Brazil.
} 


\title{
Presença de lesões intraepiteliais de alto grau entre mulheres privadas de liberdade: estudo documental
}

Objetivou-se analisar os resultados dos exames citopatológicos de mulheres privadas de liberdade. Estudo documental, retrospectivo, com abordagem quantitativa, desenvolvida em uma penitenciária feminina do Ceará, Brasil, com amostra de 672 prontuários. Quanto aos achados microbiológicos, foi verificado que a principal colonização cérvicovaginal foram os bacilos sugestivos de Gardnerella/Mobiluncus com 21,8\%, seguidos de Trichomonas vaginalis $12, \%$ e Candida $s p$ em 5,8\%. As frequências de amostras com atipias celulares mostraram índices de $4,1 \%$ para atipias de significado indeterminado; lesões intraepiteliais de baixo grau 3,2\% e lesões intraepiteliais de alto grau 2,5\%. Conclui-se sobre a importância do rastreio do câncer cervical nos presídios femininos, bem como a inserção do enfermeiro nesse ambiente, garantindo cuidado individualizado e de qualidade para as mulheres privadas de liberdade.

Descritores: Neoplasias do Colo do Útero; Prisões; Enfermagem.

\section{Presencia de lesiones intraepiteliales de alto grado a las mujeres privadas de libertad: estudio documental}

\begin{abstract}
El objetivo fue analizar los resultados de la prueba de Papanicolaou de mujeres privadas de libertad. Tipo de estudio documental, con un enfoque cuantitativo, desarrollado en una cárcel de mujeres en Ceará-Brasil, con muestra de 672 archivos. En cuanto a los resultados microbiológicos se comprobó que el principal colonización de cáncer cervicalvaginal fueron los Bacilos sugestivos de Gardnerella/Mobiluncus con 21,8\%, seguido de Trichomonas vaginalis $12 \%$ y Cándida sp 5,8\%. Las frecuencias de las muestras con atipia celular se registraron tasas de $4,1 \%$ para Atipias de significado indeterminado; Lesiones Intraepiteliales de bajo grado 3,2\% y Lesiones Intraepiteliales de alto grado $2,5 \%$. La conclusión es la importancia de la detección del cáncer cervical en las cárceles de mujeres, así como la inclusión de los enfermeros en este entorno al tiempo que garantiza una calidad y una atención individualizada a las mujeres presas.
\end{abstract}

Descriptores: Neoplasias del Cuello Uterino; Prisiones; Enfermería.

\section{Introduction}

Cervical cancer $(\mathrm{CC})$ is the second most prevalent type of cancer among women, with higher statistics only for breast cancer(1). There are several risk factors for the development of $\mathrm{CC}$, however, the human papillomavirus (HPV) is considered to be the major etiologic agent of this tumor, since $99 \%$ of the intraepithelial and invasive neoplasms of the genital tract of women are caused by infection by one of the 15 oncogenic types of HPV, with the subtypes 16 and 18 the most prevalent ${ }^{(2-3)}$. In addition to HPV, there are several risk factors for the development of the CC, such as a history of Sexually Transmitted Diseases (STDs), early initiation of sexual intercourse, smoking, low socioeconomic and educational levels, the use of oral contraceptives, multiparity, as well as a multiplicity of sexual partners and not using condoms $^{(4-5)}$. The aforementioned risk factors for the development of CC closely approach the profile of the female prison population. This group is characterized by young women, with a high prevalence of STDs, sporadic use of condoms, history of prostitution, early first sexual intercourse, and low socioeconomic and educational levels(6).

A study conducted with 2937 women in a female prison in the state of São Paulo revealed a prevalence of $16.3 \%$ of the inmates with HPV of high risk for the development of cervical cancer and $4.8 \%$ with HPV of low 
oncogenic potential. This fact reveals the vulnerability that this group has for the acquisition of STDs and for the development of $\mathrm{CC}^{(7)}$. Thus, the prison is an important site for the practice of health professionals regarding health promotion strategies involving CC and STDs. However, the majority of these activities, when they exist, are restricted to the supply of condoms, without further information on the theme ${ }^{(8)}$. This attitude is unlikely to change the sexual behavior of these women towards practicing safer sex. Educational activities that aim to change behavior must be dialogue based and participatory, with the role of health professionals, including nurses, being fundamental to recognize the specific needs of each client and, thus, to promote health through all their actions ${ }^{(9)}$.

Given the health conditions that the prison population presents, in 2003 the Prison System National Health Plan (PSNHP) was created. This plan aims to contribute to the control and reduction of the most common health injuries of the Brazilian prison population, highlighting women's health as a priority, emphasizing the control of cervical cancer, as well as diagnosis, counseling and treatment for STDs/HIV/AIDS(10). Therefore, the Pap smear is configured as essential for the control of the development of cervical cancer in the female prison population, this environment being an opportune site for screening for this neoplasm. For the implementation and consolidation of the PSNHP the presence of the nurse as a member of the healthcare team is fundamental, since the majority of the actions are based on nursing strategies of prevention and health promotion designed to improve the health of the population.

This study therefore becomes relevant since it provides knowledge regarding the prevalence of cytological lesions and microbiological alterations in this population, allowing healthcare professionals of the prison system to invest in strategies for the reduction of the risk factors and the incidence of $\mathrm{CC}$ in this population of women. Given the above, the interest emerges in knowing the health status of women prisoners with a focus on the outcome of the cytopathological examinations of women detained in the prison institution, since health actions aimed at this population are scarce, as are studies that address this issue. Thus, this study aims to analyze the distribution of cytological and microbiological findings originating from the patient records regarding the cervical cancer prevention examinations performed in women deprived of their liberty in a Prison Unit of Ceará, Brazil, as well as outlining the sociodemographic profile of this population.

\section{Methodology}

This documental, retrospective study, with a quantitative approach, was developed at the Instituto Penal Feminino of the state of Ceará, Brazil. The institution has a capacity for 300 women and represents the only women's prison in the state, being responsible for hosting all women who have been convicted in the state of Ceará(11). Gynecological consultations are performed by the gynecologists of the Institution, who perform an average of 8 to 12 consultations per day, once a week. Women who have been in the prison for more than eight months have priority over the newcomers. However, cases of gynecological emergency take overall preference.

The population consisted of all the patient records archived between January 2003 and July 2010. This period is justified by the formulation of the PSNHP by the Ministry of Health, in 2003, which culminated in the initiation of the restructuring of the prison units in order to comply with the guidelines established. The inclusion criteria were all the specific gynecological patient records. The patient records excluded from the study were the prenatal care monitoring records, as well as those dated prior to the year 2003. A total of 2322 patient records were analyzed, of these 1650 were excluded as a result of the above exclusion criteria, giving a total sample of 672 patient records. The collection period was between June and July 2010, through searching for information in the available patient records, with the use of a structured instrument based on the data form of the institution. Data collection took place in the prison in one of the healthcare service rooms of the institution, in which the patient records of gynecological consultations were stored. The data collection instrument included information regarding identification (age, education level and marital status), gynecological data (principle complaint) and the performance of prior Pap smears.

The following information was retrieved from the Papa smear reports, the sample adequacy (satisfactory and unsatisfactory), represented benign epithelium (Squamous, Glandular and Metaplastic; Squamous; Squamous and Metaplastic; Squamous and Glandular; Metaplastic, Glandular and Metaplastic; Glandular; and Absent), benign cellular alterations (mild, moderate or severe inflammation, Immature Squamous Metaplasia; Radiation; Repair; and Atrophy with inflammation), microbiology (Cocci and Bacilli; Bacilli suggestive of Gardnerella/Mobiluncus; Lactobacilli; Trichomonas vaginalis; Cocci; Candida sp; Suggestive of Chlamydia 
$s p$; Bacilli) and atypical squamous and glandular cells (No alteration; atypical cells of undetermined significance (ASCUS); Low-grade intraepithelial lesion (HPV and CIN I); High-grade intraepithelial lesion (CIN II and CIN III); Adenocarcinoma in situ; HSIL/cannot exclude micro-invasion). The data were stored and analyzed using the Statistical Package for the Social Sciences (SPSS), version 17.0, presented in tables according to the descriptive statistics and discussed in relation to the pertinent literature. The ethical aspects of research involving humans were respected, according to the criteria of Resolution 196/96, under Protocol No. 229/09 from the Research Ethics Committee of the Federal University of Ceará.

\section{Results}

Initially, the data that characterize the profile of women in the study is presented. The variables used were: age, level of education, marital status and crime for which the inmate was convicted. It is worth noting that the number of the sample differs according to the variables, due to lack of registration by the professionals in the patient records analyzed, this being a constant difficulty encountered in documental research.

In terms of age, the median found was 29 years, with a minimum of 18 and maximum of 65 years, with the interquartile range (IQR) of 12 years. From the total of 609 patient records analyzed, it was observed that $45.5 \%$ (277) of the women were young, within the age group 18 to 27 years, and 39.6\% (241) were aged between 28 and 39 years, characterizing a group of young adults. A smaller number of the women (88 - 14.4\%) were in the age group 40 to 60 years, representing the group of middle aged women, and $0.5 \%$ (3) were aged over 61 years. Considering the 127 patient records that revealed the educational level of the women in question, it was found that more than half of the sample, $69.3 \%$ (88), had incomplete primary education, with up to eight years of study and $9.4 \%$ (12) had complete primary education, with nine years of study. The percentage of illiterate women was $7.9 \%$ (10), while $17.3 \%$ (22) presented 12 years of study or complete high school education, it was also noticed that one woman had higher education with 16 years of study. Regarding the marital status of the participants, of the total 268 women the majority, 78\% (209), reported being single, while married women accounted for $11.6 \%$ (31), widowed $2.2 \%(6)$, divorced $1.9 \%$ (5) and those who had stable unions represented $6.3 \%$ (17). The distribution prevalence of the offenses committed by 643 prisoners was prepared as follows: 53\% (341) were detained for the crime of drug trafficking, followed by $25 \%$ (161) for theft, $6.4 \%$ (41) for murder and $15.6 \%$ (100) for other offenses such as receiving stolen goods, fraud and extortion through kidnap.

The most significant gynecological complaint in that study was vaginal discharge, with $24.9 \%$ (197), followed by women who had no complaints and were taking the Pap smear as routine, with $23.7 \%$ (187). The third position was occupied by the complaint of pelvic pain $14.2 \%$ (112) and other complaints, such as foul odor, vulval pruritus, dyspareunia and dysuria were presented in smaller numbers. With regard to the adequacy of the sample, it was shown that $95.5 \%$ (530) were considered satisfactory samples for analysis and $4.5 \%$ (25) appeared to be unsatisfactory. It is noteworthy that in the present study the classification regarding the adequacy of the sample was defined by only two categories: satisfactory or unsatisfactory, as recommended by the Ministry of Health(2).

Table 1 shows the data referring to the represented benign epithelium in the cytopathology reports of the women prisoners in the study, as well as the benign alterations.

Table 1 - Results of the cytopathology examination registered in the patient records of inmates in prison in Ceará, regarding the represented benign epithelium and benign cellular alterations. Aquiraz, CE, Brazil, 2010

\begin{tabular}{lcc}
\hline & $\mathbf{n}$ & $\%$ \\
\hline Represented Benign Epithelium $(\mathrm{n}=452)$ & & \\
Squamous, glandular and metaplastic & 157 & 34.7 \\
Squamous & 141 & 31.2 \\
Squamous and metaplastic & 118 & 26.1 \\
Squamous and glandular & 22 & 4.9 \\
Metaplastic & 08 & 1.8 \\
Glandular and metaplastic & 02 & 0.4 \\
Glandular & 02 & 0.4 \\
Absent & 02 & 0.4 \\
Benign Alterations ( $=654)$ & & \\
Moderate inflammation & 286 & 43.6 \\
Mild Inflammation & 168 & 25.6 \\
Severe inflammation & 96 & 14.6 \\
Immature Squamous Metaplasia & 91 & 13.9 \\
Radiation & 05 & 0.8 \\
Repair & 04 & 0.6 \\
Atrophy with inflammation & 04 & 0.6 \\
\hline
\end{tabular}


The represented benign epithelium that obtained the highest frequency was the squamous glandular and metaplastic $34.7 \%$ (157), followed by isolated squamous epithelium with $31.2 \%$ (141). Considering the benign alterations, $83.8 \%$ (550) of these related to mild, moderate or severe inflammation.

Table 2 presents the data related to the microbiological findings and atypical cells of the oncotic cytology examinations in the women prisoners of the study.

Table 2 - Results of the Pap smear recorded in the patient records of prison inmates in Ceará regarding the microbiological findings and atypical cells. Aquiraz, CE, Brazil, 2010

\begin{tabular}{lcc}
\hline & $\mathbf{n}$ & $\%$ \\
\hline Microbiological findings (n=719) & & \\
$\quad$ Cocci and bacilli & 199 & 27.7 \\
Bacilli suggestive of Gardnerella/Mobiluncus & 157 & 21.8 \\
Lactobacilli & 152 & 21.1 \\
Trichomonas vaginalis & 88 & 12.2 \\
Cocci & 65 & 9.0 \\
Candida sp. & 42 & 5.8 \\
Suggestive of Chlamydia sp. & 14 & 1.9 \\
Bacilli & 02 & 0.3 \\
Atypical Cells (n=561) & & \\
No alteration & 502 & 89.5 \\
Atypical cells of undetermined significance & 23 & 4.1 \\
(ASCUS) & & \\
Low grade intraepithelial lesion (HPV and & 18 & 3.2 \\
CIN I) & & \\
High-grade intraepithelial lesion (CIN II and & 15 & 2.7 \\
CIN III) & & \\
Adenocarcinoma in situ & 02 & 0.4 \\
HSIL cannot exclude micro-invasion & 01 & 0.2 \\
\hline
\end{tabular}

The findings reveal a marked number of women who were diagnosed with an STD, reaching $14.1 \%$ (102) if Trichomonas vaginalis and Chlamydia are grouped together. Regarding the atypical cells, it was found that $10.5 \%$ (59) had some type of atypical cell ranging from atypical cells of undetermined significance to adenocarcinoma in situ. Concerning the Pap smear, from the sample of 528 patient records analyzed it was identified that $15.3 \%$ (81) of the women had never performed the Pap smear in their life, with prison presenting the first opportunity to perform this examination.

\section{Discussion}

The sociodemographic data showed a population of young women with a median age of 29 years and low levels of education, identifying a percentage of $78.7 \%$ (100 of 127 patient records containing this information) of women who had up to nine years of study, referring to complete or incomplete elementary education. Furthermore, a frequency was found of $78 \%$ (209) of single women. A study conducted with 559 women in the prison system of the state of Rio de Janeiro, with the aim of characterizing the sociodemographic profile, prison history, drug use and presence of sexually transmitted diseases in institutionalized women, showed a mean age of 31 years among the detainees. Furthermore, this study also identified the prevalence of women who had Elementary Education, whether complete or incomplete, as $72.6 \%$, with $54.4 \%$ that reported being single, confirming the findings of the present study ${ }^{(12)}$. Many women deprived of their liberty claim the pursuit of money and lack of employment as the cause of their entrance into criminality(13). It is noteworthy that the low educational level associated with few professional qualification may be contributing factors to the increase in female criminality ${ }^{(14)}$.

One possible explanation for the high number of single women prisoners seems to be related to the sense of abandonment expressed by the inmates in the initial interview, in relation to their family ${ }^{(12)}$, this lack of a partner may be a determining factor in the feeling of loneliness expressed by the women prisoners. From the analysis of the data related to the offence committed by the woman prisoners, it can be affirmed that drug trafficking was the most frequent offense, with 53\% (341), followed by larceny/theft, 25\% (161). Among the causes most encountered there were two main forms: through criminal boyfriends/partners or of a more independent form ${ }^{(14)}$. Thus, it can be seen how the gender characteristics may be determinants for the entry of women in to drug trafficking. Further studies are necessary which include the issue of the involvement of women in crime related to drug trafficking, not excluding the possibility of the woman herself deciding to be the author of offenses without the influence of the partner. In the case of the main gynecological complaint presented by the women, it was found that vaginal discharge occupied the highest position, with $24.9 \%$ (197) of the findings, followed by the routine examination, with $23.7 \%$ (187).

A study that aimed to analyze the cytopathology reports of 194 patient records of women attending a Natural Birth Center in Fortaleza, verified findings a little higher than the data of the present study, indicating a percentage of $35.2 \%$ of gynecological complaints 
corresponding to leukorrhea and $22.4 \%$ to pelvic pain ${ }^{(15)}$. However, these are characterized as the two most common complaints in gynecological clinics in agreement with the present study. It is noteworthy that despite the life contexts being different the gynecological complaints were similar. Therefore, understanding the social determinants of health is essential to affirm the real reasons that lead women to seek the healthcare service.

An important finding was that $24.9 \%$ (197) of the women presented a complaint of leucorrhoea as the main reason for seeking the healthcare service. Such behavior is of concern, since the Ministry of Health recommends vaginal infections be treated primarily, then cytological collection performed, since the presence of pus cells may prejudice the reading of the slide, altering the result of the cytopathology ${ }^{(2)}$. The collection of material for the performance of the cytological examination, despite being simple, must be systematic and careful so that the cytologist has adequate conditions for reading the slides $^{(2)}$.

A study conducted in Porto Alegre, in order to evaluate the adequacy of the samples of 1570 cytopathology reports, identified that $0.32 \%$ of the samples were found to be unsatisfactory for analysis(16). This rate was approximately fourteen times lower when compared to the data from the present study. This raises questions about the quality of the cytological collection carried out in the prison institutions. The presence of squamous, glandular and metaplastic epithelium, or metaplastic cells in the Pap smear is characterized as indicative of good quality cytology collection, since almost always these constitute the source of the cancers of the cervix $^{(2)}$. In the present study, a controversy was noted regarding the quality of the cytologic collection, since almost the same percentage for squamous, glandular and metaplastic (34.7\%) and isolated squamous $(31.2 \%)$ epitheliums was observed. It is for the health professional responsible for the collection to evaluate the necessity of a repetition of the examination in cases of the exclusive presence of squamous cells, considering the fact that the woman is not being provided with all the benefits that the Pap smear offers in the prevention the CC.

Continuing the analysis of the cytological reports of the women deprived of their liberty, the frequencies of benign cellular alterations encountered were $25.6 \%$ (168) for mild inflammation, $43.6 \%$ (286) for moderate inflammation and $14.6 \%$ (96) for severe inflammation. A study with 1780 women attending the preventive gynecology outpatient clinic of a hospital in Rio de
Janeiro, between 2004 and 2005, found that 90.2\% presented inflammatory alterations of the vagina and/ or cervix, confirming the high prevalence found in the present study ${ }^{(17)}$. These data show that the inflammatory processes present in the cytopathology reports present a high prevalence, thus requiring an explanation for the women of the significance of this finding, in simple and easily understood language, as many of them believe that this inflammation always characterizes a pathological process, rather than a physiological one as is usually the case.

Regarding the distribution of the findings related to the microbiological causes of pathologies, it was observed that the majority of cervical-vaginal colonizations were by the bacilli suggestive of Gardnerella/Mobiluncus with $21.8 \%$ (157), followed by the microorganism Trichomonas vaginalis in $12 \%$ (88) of the cases. Candida $s p$ represented $5.8 \%$ (42) of the reports and suggestive of Chlamydia $s p$ was present in only $1.9 \%$ (14) of the reports. Comparing the above results with data from the general female population, a study that aimed to analyze the prevalence of cervicitis and its microbiological agents with a sample of 500 routine cervical-vaginal smears from the of Pathology Division of the National Cancer Institute (DIPAT-INCA) identified the percentage of $21.8 \%$ of microbiota suggestive of Gardnerella/Mobiluncus and $2.4 \%$ Candida sp., which is in agreement with the findings of the present study ${ }^{(18)}$. Few published studies exist related to women's health problems and their forms of prevention in Brazilian prisons, more specifically related to the sexually transmitted infectious diseases ${ }^{(19)}$. However, when they exist, their focus is primarily on the prevalence of HIV, Hepatitis $C$ and Syphilis leaving gaps related to the more common diseases like trichomoniasis and chlamydia, which also cause serious gynecological and obstetrical damage, including Pelvic Inflammatory Disease (PID) and infertility.

Referring again to data from the study that aimed to analyze the prevalence of cervicitis and its microbiological agents with a sample of 500 cervical-vaginal smears, the percentages of $4.3 \%$ for trichomoniasis and $0.5 \%$ suggestive of Chlamydia sp. were observed, percentages well below those found in the present study. The high prevalence of trichomoniasis and chlamydia in prisons can be explained by the high level of promiscuity that takes place in this environment, the precariousness of the preventive control of STDs, the lack of condom use in homosexual relationships and constant changes in sexual partnerships. 
Regarding the atypical cells, the result of atypical squamous cells of undetermined significance (ASCUS) was the most important premalignant alteration, accounting for $4.1 \%$ (23) of the reports. Corroborating these findings a study conducted in the state of São Paulo with 5485 women found a rate of $3.8 \%$ for the diagnosis of $\operatorname{ASCUS}^{(20)}$. This finding, even though approaching the level of the present study, presents a lower rate of ASCUS. Despite not being able to completely confirm that women deprived of their liberty are more susceptible to the development of atypical alterations than the general population, attention should be paid to these clients, investing in actions to ensure good quality gynecological monitoring for the prisoners. The second most frequent premalignant alteration was low grade intraepithelial lesions (HPV and CIN I), with $3.2 \%(18)$ of the total. A study aimed at analyzing the behavior of precursor lesions of cervical cancer among adolescents in the municipality of Rio de Janeiro from 1998 to 2005, with 1,516,407 cytology examinations collected, identified the percentage of $4.66 \%$ of low grade intraepithelial lesions in the adolescents ${ }^{(21)}$. In relation to the findings regarding high-grade intraepithelial lesions (CIN II and CIN III), a rate of $2.5 \%$ (15) was observed. These lesions have a higher probability of evolving into $\mathrm{CC}$ and therefore deserve greater attention from the professionals.

Various studies conducted in Brazil with substantial samples found rates of high-grade intraepithelial lesions (CIN II and CIN III) ranging from $0.3 \%$ to $0.94 \%{ }^{(21)}$. The data found in the present study showed a higher rate than those encountered in the literature. Considering that the profile of the female study population relates to women of low educational levels, and that many of them had no access to healthcare services before entering prison, these findings may indicate a direction in which the strategies to combat CC should be intensified. Data from the present study revealed that $15.3 \%$ (81) women had never performed the Pap smear prior to entering prison. In this context, the controlled prison environment is configured as a unique opportunity in the process of preventive healthcare, as well as for the monitoring and appropriate treatment of various diseases, including cervical cancer. Actions such as regular Pap smears and ensuring continuity of care to the woman can benefit everyone, the individual, the community and society, leading to a reduction in the incidence of the $\mathrm{CC}$, as well as a reduction in costs for the health services.

It can be confirmed that among the limitations of the study is the lack of adequate registration by the professionals in the patient records analyzed, as well as the lack of important information to characterize the sociodemographic profile and description of the sexual behavior of the subjects. Added to this is the bureaucracy for conducting research in the Prison Institute.

\section{Conclusion}

The profile of the women deprived of their liberty demonstrates a young population with low levels of education, without stable permanent unions, and, most commonly, convicted of drug trafficking offenses. Regarding the result of the cytological reports referring to the alterations, a predominance of moderate inflammation was observed, with a high rate of trichomoniasis, bacterial vaginosis, as well as a high prevalence of atypical squamous cells of undetermined significance. Given the above, it can be concluded that it is extremely important to screen for CC and the prevalence of STDs in female prisons, in order to create concrete changes in the prison healthcare systems, especially the gynecological services. These changes should include the effective implementation of appropriate scheduling of consultations, with a sufficient number of professionals in order to ensure individualized, quality care for the women deprived of their liberty, based on the principle of universality advocated by the Brazilian National Health Service (SUS), in which all individuals have the right to health, whether they have violated the laws of society or not. Thus, the prison environment can be considered as a great opportunity for screening for CC, as well as for other diseases, being a highly favorable space for the inclusion of health promotion strategies in the quest for improved quality of life for the female inmates. Finally, the important role is emphasized that health professionals, including nurses, play in promoting the sexual and reproductive health of these women prisoners, who are on the margins of society, separated from the world, not only by prison walls, but mainly by invisible walls of prejudice that exist on the part of society.

\section{References}

1. Ministério da Saúde (BR). [Internet]. Instituto Nacional do Câncer. Coordenação de Prevenção e Vigilância. Estimativas de incidência e mortalidade por câncer no Brasil 2010; 2010 [acesso 15 mai 2010]. Disponível em: http://www.inca.gov.br/estimativa/2010/index. asp?link=conteudo_view. asp\&ID = 5 
2. Ministério da Saúde (BR). Instituto Nacional do Câncer. Secretaria de Saúde (SP). Fundação Oncocentro. Condutas Clínicas Frente aos Resultados do Exame Papanicolaou. Brasília (DF): Conselho Nacional de Saúde; Ministério da Saúde; 2005. 72 p. Relatório Final. 3. Silva TT, Guimarães ML, Barbosa MIC, Pinheiro MFG, Maia AF. Identificação de tipos de papilomavirus e de outros fatores de risco para neoplasia intra-epitelial cervical. Rev Bras Ginecol Obstet. 2006;28(5):258-91.

4. Lima CA, Palmeira JAV, Cipolotti R. Risk factors for cancer of the uterine cervix in Propriá, Sergipe, Brazil. Cad Saúde Pública. 2006;22(10):2151-6.

5. Rosa MI, Medeiros LR, Rosa DD, Bozetti MC, Silva FR, Silva BR. Papilomavírus humano e neoplasia cervical. Cad Saúde Pública. 2009;25(5):953-64.

6. Strazza L, Massad E, Azevedo RS, Carvalho HB. Estudo de comportamento associado à infecção pelo HIV e HCV em detentas de um presídio de São Paulo, Brasil. Cad Saúde Pública. 2007;23(1):197-205.

7. Lopes F, Latorre MRDO, Pignatari ACC, Buchalla CM. Prevalência de HIV, papilomavírus humano e sífilis na Penitenciária Feminina da Capital, São Paulo, 19971998. Cad Saúde Pública. 2001;17(1):1473-80.

8. Rangel H. Estratégias sociais e Educação Prisional na Europa: visão de conjunto e reflexões. Rev Bras Educ. 2007;12(34):81-93.

9. Leonello VM, Oliveira MAC. Competências para ação educativa da enfermeira. Rev. Latino-Am. Enfermagem. 2008;16(2):177-83.

10. Ministério da Saúde (BR). Departamento de Ações Programáticas Estratégicas. Plano Nacional de Saúde no Sistema Penitenciário. Série B. Textos Básicos de Saúde. Brasília (DF): Conselho Nacional de Saúde; Ministério da Saúde; 2005. 64 p. Relatório Final.

11. Secretaria de Justiça e cidadania do estado do Ceará (BR). Unidades prisionais [Internet]. Ceará: SEJUS; 2008. [acesso 15 mai 2010]. Disponível em: http://www. sejus.ce.gov.br/index.php/gestao-penintenciaria/39/69 2008

12. Carvalho ML, Valente JGA, Assis SG, Vasconcelos AGG. Perfil dos internos no sistema prisional do Rio de Janeiro: especificidades de gênero no processo de exclusão social. Ciênc Saúde Coletiva. 2006:11(2):461-71.

13. Guimarães CK, Santos EG, Pestana VR, Wally APS. Perfil da detentas da unidade prisional de Tabatinga. $16^{\circ}$ Congresso de Iniciação Científica; 27-29 novembro 2007; Pelotas, Rio Grande do Sul. Pelotas: UFPI; 2008. p. 1-5.
14. Lopes RMF, Mello DC, Argimon II. Mulheres encarceradas e fatores associados a drogas e crimes. Ciênc Cogn. 2010;15(2):121-31.

15. Leitão NMA, Pinheiro AKB, Anjos SJSB, Vasconcelos CTM, Nobre RNS. Avaliação dos laudos citopatológicos de mulheres atendidas em um serviço de enfermagem ginecológica. Rev Min Enferm. 2008;12(4):508-15.

16. Irion CI, Buffon A. Avaliação da adequabilidade das amostras de exames citopatológicos realizados em um laboratório de Porto Alegre - RS no ano de 2000. RBAC. 2009;41(3):217-20.

17. Souza LG, Vianna ACC. Análise dos exames colpocitológicos de clientes atendidas pelo ambulatório de ginecologia preventiva do Hospital Geral de Bonsucesso-RJ, no período entre maio/2004 e abril/2005. Novo Enfoque Rev Eletrôn. [periódico na Internet]. 2010 [acesso 18 mai 2010];5:1-16. Disponível em: http://www.castelobranco.br/sistema/novoenfoque/ files/05/03.pdf

18. Tavares TG, Krunn P, Costa EI, Padilha CML, Pinto AP. Cervicitis, and its agents in the pap smear routine, DST - J Bras Doenças Sex Transm. 2007;19(1):30-4.

19. Maestri E, Tagliari D, Prada GW. Prevenção do HIV/ aids: um desafio da enfermagem no prcesso de educar atrás das grades. 6a Semana de Ensino, Pesquisa e Extensão. Florianópolis; 16-19 maio 2007; Florianópolis, Santa Catarina. Florianópolis: UFSC; 2007. p. 153.

20. Rama $\mathrm{CH}$, Roteli-Martins C, Derchain S, LongattoFilho A, Gontijo RC, Sarian LOZ, et al. Rastreamento anterior para câncer de colo uterino em mulheres com alterações citológicas ou histológicas. Rev Saúde Pública. 2008;42(3):411-9.

21. Pedrosa ML, Mattos IE, Koifman RJ. Lesões intraepiteliais cervicais em adolescentes: estudo dos achados citológicos entre 1999 e 2005, no Município do Rio de Janeiro, Brasil. Cad Saúde Pública. 2008;24(12):2881-90.
Received: July $18^{\text {th }} 2011$ Accepted: Mar. $2^{\text {nd }} 2012$ 